\title{
The 'decoada' phenomenon effect on the Paraguay river water quality, Northern Pantanal
}

In the Pantanal, during the beginning of the flooding hydrological phase occurs a natural phenomenon called 'decoada'. Characterized by the water quality alteration of the rivers, in floodplain areas and marginal lagoons, with the possibility of significant fish mortality, depending on the changes' magnitude. For this purpose, throughout a hydrological cycle (July 2018 to June 2019), precipitation, bathymetry and water quality were monitored monthly, in 6 sampling points, to determine, the moment, duration and intensity of the decoada, and its effects on water quality in the Paraguay River, northern Pantanal, near the municipality of Cáceres/MT. The dissolved oxygen (DO) concentration was used as an indicator, in which $\mathrm{DO}<3.0 \mathrm{mg} / \mathrm{L}$, during the flood season, was considered indicative of the potential event occurrence. According to the records, there were different hydrological periods, where the flooding and high waters presented DO values lower than in the dry and ebb phases, with a drastic change from October 2018 ( $D O=6.37 \pm 0.17 \mathrm{mg} / \mathrm{L}$ ) to November 2018 ( $D O=2.78 \pm 0.05 \mathrm{mg} / \mathrm{L}$ ), registering, therefore, in all points, low-intensity decoada. The DO values remained below $5 \mathrm{mg} / \mathrm{L}$, the maximum limit allowed by CONAMA Resolution $357 / 2005$ for class II rivers. From November 2018 to April 2019 in all sampling points, the minimum value was recorded in March 2019 in the bay, with DO=1.84 mg/L, considered a medium leve decoada. The principal component analysis (PCA), proved the results difference of decoada found in the river and the bay, presented with greater intensity and duration in the bay. The parameters that influenced the decoada, according to the $\mathrm{PCA}$, were $\mathrm{pH}$, temperature, precipitation, turbidity and $\mathrm{DO}$.

Keywords: Dissolved Oxygen; Hydrological Periods; Floodplain.

\section{Efeito do fenômeno 'decoada' na qualidade da água do rio Paraguai, Pantanal Norte}

\begin{abstract}
No Pantanal, destaca-se a ocorrência de um fenômeno natural denominado regionalmente como 'decoada', que ocorre durante o início da fase hidrológica de enchente. Caracterizado pela alteração da qualidade da água dos rios, em suas áreas de planície de inundação e em suas lagoas marginais, podendo ocorrer expressivas mortandades de peixes, dependendo da magnitude das alterações. Para tanto, ao longo de um ciclo hidrológico (julho/2018 a junho/2019), foram monitorados mensalmente, em 6 pontos de amostragem, a precipitação, batimetria e qualidade da água, com o objetivo de determinar, o momento, duração e intensidade da decoada, e seus efeitos na qualidade da água no rio Paraguai, Pantanal Norte, próximo a cidade Cáceres-MT. A concentração de oxigênio dissolvido (OD) foi utilizada como indicador, em que $O D<3.0 \mathrm{mg} / \mathrm{L}$ durante a época de inundação foi considerado indicativo de ocorrência potencial do evento. De acordo com os registros, verificou-se períodos hidrológicos distintos, onde a enchente e cheia apresentaram valores de OD inferiores a estiagem e vazante, havendo uma mudança drástica de outubro $/ 2018(\mathrm{OD}=6.37 \pm 0.17 \mathrm{mg} / \mathrm{L}$ ) para novembro $/ 2018(\mathrm{OD}=2.78 \pm 0.05 \mathrm{mg} / \mathrm{L}$ ), registrando, portanto em todos os pontos, decoada considerada de intensidade nível baixo. Os valores de OD, permaneceram abaixo de $5 \mathrm{mg} / \mathrm{L}$, limite máximo permitido pela Resolução CONAMA $357 / 2005$ para rios classe II, de novembro/2018 até abril de 2019 para todos os pontos de amostragem, registrando o seu valor mínimo em março/2019 na baía, com OD = 1.84 mg/L, considerada uma decoada de nível médio. A análise de componentes principais (PCA), comprovaram a diferença dos resultados de decoada encontrados no rio e na baía, que se apresentou com maior intensidade e duração na baía. Os parâmetros que influenciaram a decoada, segundo a PCA, foram pH, temperatura, precipitação, turbidez e OD.
\end{abstract}

Palavras-chave: Oxigênio Dissolvido; Períodos Hidrológicos; Planície de Inundação.

Topic: Planejamento, Gestão e Políticas Públicas Ambientais

Reviewed anonymously in the process of blind peer.
Received: 09/08/2020

Approved: $25 / 09 / 2020$
Mauri Queiroz de Menezes Junior (iD

Universidade do Estado de Mato Grosso, Brasil

http://lattes.cnpq.br/2592919935039774

http://orcid.org/0000-0001-6999-0637

mauri queiroz1@hotmail.com

Ernandes Sobreira Oliveira (iD

Universidade do Estado de Mato Grosso, Brasil

http://lattes.cnpq.br/7461346615427709

http://orcid.org/0000-0002-6953-6917

ernandes.sobreira@gmail.com

Célia Alves de Souza (iD

Universidade do Estado de Mato Grosso, Brasil

http://lattes.cnpq.br/4260661798494235

http://orcid.org/0000-0002-9068-9328

celiaalvesgeo@globo.com

\section{Referencing this:}

MENEZES JUNIOR, M. Q.; OLIVEIRA JUNIOR, E. S.; SOUZA, C. A.. The 'decoada' phenomenon effect on the Paraguay river water quality, Northern Pantanal. Revista Ibero Americana de Ciências Ambientais, v.11, n.5, p.612-623, 2020. DOI: http://doi.org/10.6008/CBPC2179$\underline{6858.2020 .005 .0055}$ 


\section{INTRODUCTION}

In the Mato Grosso Pantanal, annual and interannual dry and flooding cycles (flood pulse) are an important hydrological phenomenon for the ecological functioning of this floodplain, playing a role in controlling the structure and functioning of these ecosystems (JUNK et al., 1989). The maintenance of an initial succession state in this floodplain, as a result of constant renewal through periodic flooding, favors high productivity (JUNK et al., 1989). The flood pulse, then, is the main factor that regulates the functioning of rivers with floodplains, influencing the hydric, biogeochemical and ecological dynamics (JUNK et al., 1989; ALHO, 2011; GONÇALVES et al., 2011).

The hydro-ecological processes that occur in the vast area of river-plain interaction form a natural limnological phenomenon regionally called "decoada" (CALHEIROS et al., 1997). This phenomenon occurs during the beginning of the flooding phase, when the rising waters towards the floodplain areas receive the organic matter in decomposition from the previously flooded environments, causing a rapid oxygen reduction and an increase in dissolved carbon dioxide (OLIVEIRA et al., 2013; ANDRADE et al., 2015).

Studies carried out on the Paraguay River plain by Hamilton et al. (1995); Calheiros et al. (2000), Calheiros et al. (2010) observed that in the "decoada" phase there is a series of natural transformations in water quality, in its physical, chemical and biological parameters, as a result of the initial interaction between water in the flooded area, soil and vegetable biomass previously dried.

As the water overflows the river channel and goes into contact with the floodplain, submerging soil and vegetation in the initial phase of the flood, the processes of decomposition of the newly submerged organic material, mainly grasses of easy decomposition, begin to occur. Given this scenario, the decomposition processes are favored and enhanced by the high summer temperatures, also the period of flooding in the Pantanal (CALHEIROS et al., 1998; CALHEIROS, 2003). This activity is very intense that the organic matter oxidation by bacteria can consume all the dissolved oxygen (DO) in the water column, gradually turning the environments hypoxic or anoxic and releasing free carbon dioxide (free $\mathrm{CO}_{2}$ ) (HAMILTON et al., 1995; ANDRADE et al., 2015).

Besides, as a result of the intense decomposition, there is a change in the physical and chemical water parameters (water transparency, hydrogen potential, electrical conductivity, dissolved gas concentration oxygen, carbon dioxide and methane, nutrients - nitrogen, carbon and phosphorus, and suspended material) (CALHEIROS et al., 1996). This phenomenon influences the nutrients cycling (biogeochemical cycles) and the energy transfer between the links of the trophic chain, which are the factors that mediate the interactions between terrestrial and aquatic environments in flooded areas (SILVA, 2007). All these interrelationships promote the occurrence of the natural phenomenon of water quality deterioration (decoada), capable to cause fish deaths, according to its magnitude (Ferraz de Lima et al., Sd; Resende et al., Nineteen ninety). Limiting, for instance, fishing, given that fish species suffer respiratory stress (CALHEIROS et al., 2000) reducing feeding, consequently affecting the fisheries.

This phenomenon occurs across the floodplain and gradually moves through the downstream 
drainage system. After this initial phase of large nutrients availability and ions, as the result of decomposition, the tendency is the system gradually use such compounds, through self-purification, to improve the ecological water quality and return to the natural conditions of each aquatic ecosystem (CALHEIROS et al., 2000; OLIVEIRA et al., 2013; ANDRADE et al., 2015).

The decoada is described mainly in areas of the southern Pantanal, due to the gradual and water slow flow from the Paraguay River. In areas of the northern Pantanal, this phenomenon was represented as low intensity (OLIVEIRA et al., 2013). However, even at low intensity, this phenomenon alters water quality standards, intrinsic to human bathing, reducing the oxygen concentration, $\mathrm{pH}$, as well as altering other variables such as the $\mathrm{CO} 2$ which increase in the water culminate in fish mortality. The CONAMA Resolution standards, for instance, limit the oxygen concentration at the minimum of $5 \mathrm{mg} / \mathrm{L}$ and the $\mathrm{pH}$ between 6 and 9.0 to be considered as of quality for uses in a) supply for human consumption, after conventional treatment; b) the protection of aquatic communities; c) the primary contact recreation, such as swimming, water skiing and diving, according to CONAMA Resolution no 274, of 2000; d) irrigation of vegetables, fruit plants and parks, gardens, sports and leisure fields, with which the public may come into direct contact; and e) aquaculture and fishing. (Class II - CONAMA Resolution no. 357 for freshwaters).

In this aspect, considering the need to expand knowledge about the effects of the flood pulse in the northern Pantanal and the effect of the decoada on the physical-chemical parameters, this research aims to determine the decoada time, duration and intensity, and its effects on environmental quality in the Paraguay River, near the municipality of Cáceres-MT.

\section{METHODOLOGY}

\section{Study area}

Inserted in the Upper Paraguay Basin (BAP), the Pantanal biome represents the largest continuous floodplain on the planet, with an area of about 140 thousand $\mathrm{km}^{2}$ (SILVA et al., 1998; BRASIL, 1997). The Pantanal plain comprises, in general, areas below 200 meters of altitude, which directly depend on interactions with the plateau region, located around the Pantanal (SILVA et al., 1998).

The Paraguay River, in turn, is one of the main lowland rivers in Brazil (ZANI et al., 2008) and the main former of BAP. Its headwaters are located on the slopes of the Serra dos Parecis in the northern region of the state of Mato Grosso, flowing towards the south to the confluence with the Paraná River in the region of Corrientes, Argentina (CARVALHO, 1986).

The study area of the present work corresponds to a Paraguay River section, close to the municipality of Cáceres-MT, this segment is located between the geographical coordinates $16^{\circ} 3^{\prime} 32.00^{\prime \prime}$ and $16^{\circ} 4^{\prime} 21.00^{\prime \prime}$ of latitude south and $57^{\circ} 41^{\prime \prime} 29.00^{\prime \prime}$ and $57^{\circ} 41^{\prime} 59.00^{\prime \prime}$ of west longitude. Six sampling points were defined in this urban section of the Paraguay River (Figure 1), where four points were in the main channel of the Paraguay River and two points in an oxbow-lake in the urban area border. 


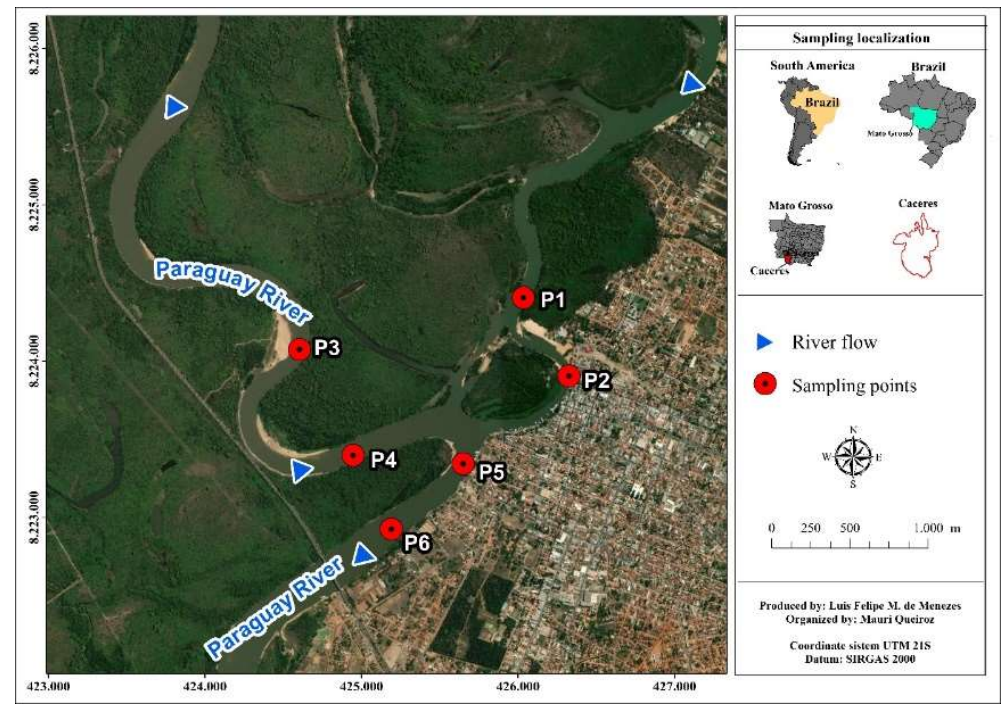

Figure 1: Study area location and the monitored points on the Paraguay River, around the urban area of Cáceres (MT), with P1 and P2 located in the bay and P3-P6 on the main channel of the Paraguay River.

The municipality of Cáceres has a population estimated by the IBGE, in 2019, of 94376 inhabitants and is located on the left bank of the Paraguay River. Several economic and social activities depend on this river, such as fishing, leisure, tourism, bathing, livestock and public supply.

\section{Methodological procedures}

For this research development, in addition to the water quality, the occurrence of rainfall in the region and its influence on the water flow was evaluated. These measurements and analyses allow the correlation the hydrological periods of the year with the possible occurrence of the decoada, whose methods are detailed below.

\section{Precipitation check}

The monthly data of precipitation, from the automatic meteorological station in the municipality of Cáceres-MT, code no. 01657003, located in the geographical coordinates Latitude: -16.074740 o and Longitude: -57.6930470 , available in the HidroWeb application of the National Water Agency (Agência Nacional das Águas - ANA) were used. This station was chosen due to its proximity to the sampling points.

\section{Vazão (Q)}

In the field, to obtain the speed values, the MLN 7 - 200.09.15 fluviometric windlass was used, measured at different points of the transversal and vertical sections, at 20,50 and $80 \%$ of the depth found. The width was obtained through satellite images, with the date closest to the day of collection. For depth, the GARMIN echomap 50s sonar was used. The variables obtained to verify the channel hydrodynamic behavior of the were determined and measured according to Cunha et al. (2009):

$$
\begin{aligned}
& \text { W- Width }(\mathrm{m}) \\
& \text { D-Depth }(\mathrm{m}) \\
& \mathrm{S}-\mathrm{Speed}(\mathrm{m} / \mathrm{s})
\end{aligned}
$$




\section{A - Area of wet section $\left(\mathrm{m}^{2}\right)$$$
\text { F - Flow }\left(\mathrm{m}^{3} / \mathrm{s}\right)
$$

Therefore, the area of wet section $(A)$ is the product of the $W \times D$ ratio $(A=W \times D)$; the flow is the product between $S \times A(F=A \times S)$.

\section{Water quality}

Regarding the water quality monitoring, at the sampling points, a multiparametric probe Hach $\mathrm{HQ} 40$ was used to measure in the field the dissolved oxygen $(\mathrm{mg} / \mathrm{L})$, electrical conductivity $(\mu \mathrm{m} / \mathrm{s})$, water temperature $\left({ }^{\circ} \mathrm{C}\right)$ and $\mathrm{pH}$. Continuously, the calculation of the average value was carried out based on the three measures executed subsequently. The turbidity parameter (NTU) was also measured in the field, using a portable Policontrol Turbidimeter, model AP 2000.

For the suspended solids (SS) determination of each sampling point, water was collected in plastic bottles of $1 \mathrm{~L}$, stored in refrigeration, which were later sent to the Laboratory of Research and Studies in Fluvial Geomorphology - LAPEGEOF of the State University of Mato Grosso-UNEMAT/Cáceres-Mato Grosso, Brazil, and was analyzed by the evaporation method. For the analysis of this parameter, the integrated collection was made in the entire water column using a Van Dorn bottle.

\section{Sampling period and data processing}

Sampling was performed monthly between July 2018 and June 2019 at six points, totalling 12 collections. For a better results understanding, the data obtained were separated by collection points (P1 to P6), by environment type (river and bay), hydrological period (dry, flooding, flooded and ebb), as elaborated by Oliveira et al. (2000) in prep and with or without decoada (DO $<3.0 \mathrm{mg} / \mathrm{L}$ with decoada, and $>3.0 \mathrm{mg} / \mathrm{L}$ without decoada), according to the classification prepared by Oliveira et al. (2013). Subsequently, the T-test was used to compare treatments and statistical significance $(p<0.05)$ to perform correlations and linear regression. All statistical tests were performed using the Office Package (Excel 2016) and the software PAST 3.0 (HAMMER et al., 2001). As a method of samples ordination, the decoada presence or absence, the Principal Component Analysis (PCA) was applied, using the Euclidean distance, performed in PAST 3.0.

\section{RESULTS AND DISCUSSION}

The rainfall in the northern Pantanal in the period of this study had a total of $1212.8 \mathrm{~mm}$, with an average of $101.1 \pm 109.8 \mathrm{~mm}$, close to that found by Neves et al. (2012) and Buhler (2011) for the same location. However, these authors found the highest monthly rainfall between December, January and February, differently from what was found in this study, where October presented the highest rainfall, with $330.4 \mathrm{~mm}$ (Figure 2).

There was no statistically significant relationship between monthly precipitation and the average flow of the points of the Paraguay River $(p>0.05)$ and bay $(p>0.05)$. This fact is due to the low slope of the BAP, which causes a slow flow, first filling the main river channel, and then the bay (Brazil, 1979). In this way, 
precipitation does not immediately influence the flow, as verified in the month of September, that rained $161.6 \mathrm{~mm}$, higher than the expected for this month. According to Neves et al. (2012) the expected precipitation for this month is $50.96 \mathrm{~mm}$, however not showing a considerable flow increase, compared to the previous month (August), increasing considerably in the subsequent month (October), affecting more the points located on the Paraguay River, which had an average $140.2 \%$ of flow increase.



Figure 2: The average flow of the bay (P1 and P2; dotted lines) and river (P3, P4, P5 and P6; dashed line) in the study period, and the average rainfall of each month (bars).

When analyzing the average dissolved oxygen at the sampling points according to the seasonal periods (Figure 3) and between bay and river (Figure 4), it is observed that the flooding and the flooded periods show lower values of dissolved oxygen than in the dry and in the ebb periods, meeting the research previously prepared for the Brazilian Pantanal (BASTVIKEN et al., 2010; CALHEIROS, 2003; HAMILTON et al., 1995). These authors report that the average DO concentration of the Paraguay River is above $5 \mathrm{mg} / \mathrm{L}$, but reach values lower than $3.0 \mathrm{mg} / \mathrm{L}$ during the high-water period (flooding/flooded). And that, the oxygen concentrations in marginal bays can reach anoxia, therefore confirming that the annual decoada events occur during the flooding and flooded periods in the northern Pantanal, particularly around Cáceres.

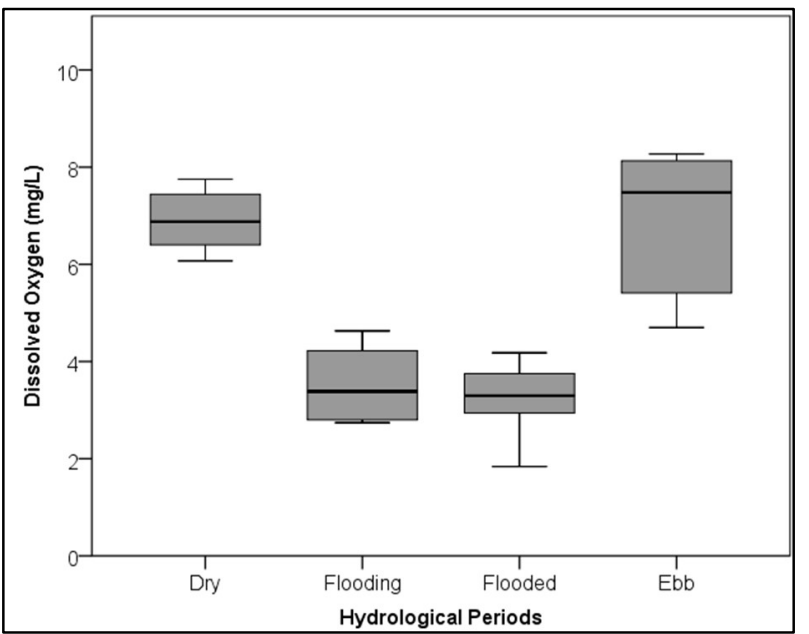

Figure 3: Dissolved oxygen dynamics in the sampling points (P1 to P6) during the characteristic hydrological periods of the northern Pantanal.

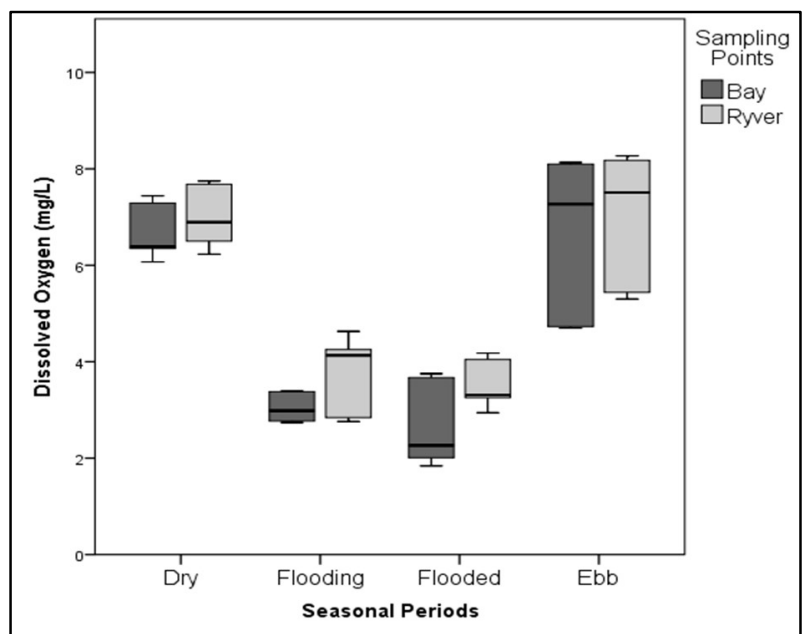

Figure 4: Dissolved oxygen dynamics evidencing the bay (P1 and P2) and the Paraguay River (P3 to P6) during the characteristic hydrological periods of the northern Pantanal. 
Oliveira et al. (2013) proposed a classification related to the intensity level of the decoada, considering dissolved oxygen, where, high intensity: it is when the observed DO concentration was less than or equal to $1.0 \mathrm{mg} / \mathrm{L}$, average: when DO was between 1.0 and $2.0 \mathrm{mg} / \mathrm{L}$ and low: when DO concentration was between 2.0 and $3.0 \mathrm{mg} / \mathrm{L}$.

The dissolved oxygen demonstrated that for 12 months (between 2018 and 2019) there was no significant difference between the sample points (P1 to P6) ( $p>0.05)$. However, the months were quite different, with drastic changes from one month to another, particularly between October and November. The average dissolved oxygen of the points was $6.37 \pm 0.17 \mathrm{mg} / \mathrm{L}$ in October, while in November the oxygen was $2.78 \pm 0.05 \mathrm{mg} / \mathrm{L}$ (Figure 05), characterizing the "decoada", with an intensity level considered low, according to classification elaborated by Oliveira et al. (2013).

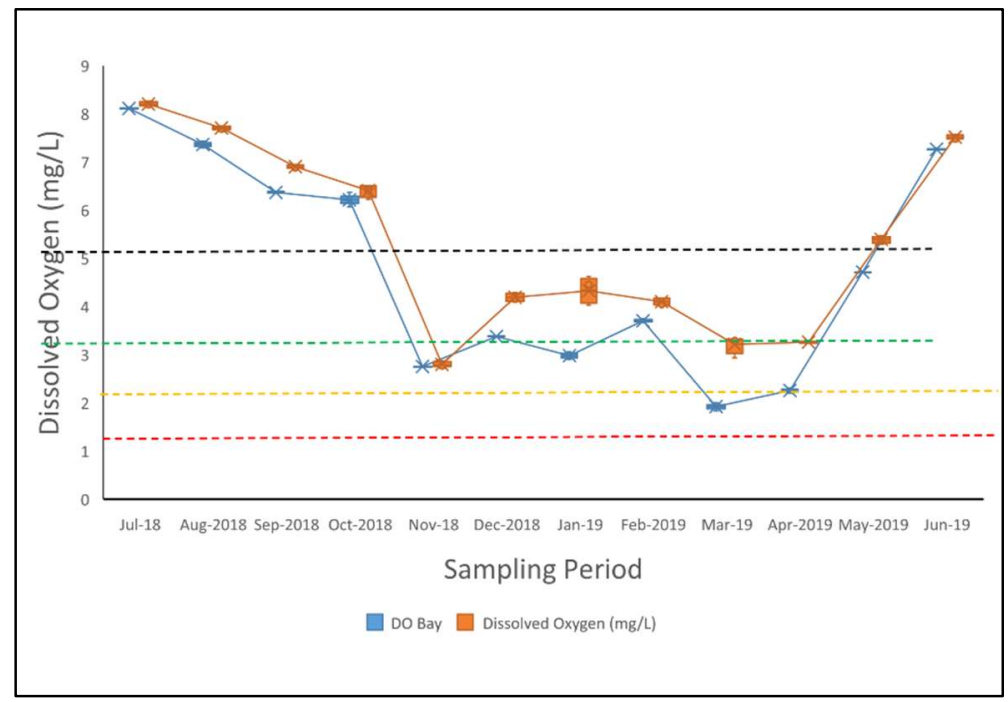

Figure 2: Dissolved oxygen dynamics in the bay and river during the study period. Intensity of decoada events, were defined according to elaborated by Oliveira et al. (2013), considering the minimum DO concentration in the water, as high $(\mathrm{DO} \leq 1.0 \mathrm{mg} / \mathrm{L})=$ red color; medium $(\mathrm{DO}$ between 1.0 and $2.0 \mathrm{mg} / \mathrm{L})=$ yellow and $\mathrm{low}(\mathrm{DO}>2.0<3.0 \mathrm{mg} / \mathrm{L})=$ green color. The limit established by CONAMA, for class II rivers, of $5.0 \mathrm{mg} / \mathrm{L}$ (black color) was also considered.

The Paraguay River had an average dissolved oxygen of $5.33 \pm 1.87 \mathrm{mg} / \mathrm{L}$, while the bay had average oxygen of $4.75 \pm 2.15 \mathrm{mg} / \mathrm{L}$. In the comparison between river and bay, no statistical differences were observed ( $p>0.05$ ). However, when we consider only periods when oxygen was below $3 \mathrm{mg} / \mathrm{L}$, in bay locations, this variable was $17 \%$ lower than in the Paraguay river ( $T$-test; $t=2.29 ; p<0.05$ ). The number of DO records $<3.00 \mathrm{mg} / \mathrm{L}$, was higher in the bay $(n=7)$ than in the river $(n=5)$, occurring in the months of November, January, March and April in the bay; and only in November and March on the river.

The non-occurrence of decoada in the months of flooding and flooded phases may be related to rainfall below the expected average for November $(147.04 \mathrm{~mm})$, December $(213.61 \mathrm{~mm}$ ) and January $(244.94$ $\mathrm{mm})$, raining above the expected average only in February $(198.92 \mathrm{~mm})$ according to the work carried out by Neves et al. (2012).

During these months the average was $49.4 \mathrm{~mm}$ in November, $96.2 \mathrm{~mm}$ in December and $135.2 \mathrm{~mm}$ in January. This fact may have caused an increase in oxygen levels in December, January and February in the Paraguay River channel. Subsequently, rainfall above the average $(268 \mathrm{~mm})$ occurred in February, reflected 
in the lowest value of dissolved oxygen registered in this work, in March $(1.84 \mathrm{mg} / \mathrm{L})$, for the point P1 (bay), registering, therefore, an event considered of medium intensity, not yet registered for the Pantanal Norte, particularly by Oliveira et al. (2013). It can be inferred, therefore, that higher average rainfall may increase the intensity of the decoada in this region.

The decoada event continued in April, only in the bay ( $D O=2.26 \mathrm{mg} / \mathrm{L}$ ). In the Paraguay River, the only point that registered the phenomenon, in addition to November, was P6, with $2.94 \mathrm{mg} / \mathrm{L}$ in March, probably due to receiving water from the marginal bay (Figure 1). The SEMA (MOTO GROSSO, 2018), when monitoring the Paraguay river water quality in stretches upstream and downstream in Cáceres/MT, also found higher values for DO in the dry and lower values in the flooded periods, with a record of $1.61 \mathrm{mg} / \mathrm{L}$ in March 2017, denoting the regularity of this event, and again, the lowest value found in March.

When comparing the results with the CONAMA Resolution no 357/2005 standards for Class II rivers, all points analyzed in this study showed values below the recommended (minimum limit of $5 \mathrm{mg} / \mathrm{L}$ for DO), in the months between November and April. Oliveira et al. (2013), mapping and describing the decoada events areas in the Pantanal, reported that in the north of the Paraguay River, the decoada was less expressive, of low intensity ( $\mathrm{DO}>2<3 \mathrm{mg} / \mathrm{L}$ ) and short duration (1 to 2 months) and usually at the end of the rainy season, between February and March. However, as seen in this work, this event can occur with medium intensity, and, depending on the rain, it can start in November and last more than 2 months.

A negative relationship was observed between the values of water temperature and dissolved oxygen (Figure $6, R^{2}=0.32 ; p<0.05$ ), which presented mean values of $27.36 \pm 2.22 \stackrel{\circ}{ }$, with a minimum value of $22.1^{\circ} \mathrm{C}$ in July and maximum $31.2^{\circ} \mathrm{C}$ in October. The values above the average were between the months of September and April, supporting the Bastviken et al. (2010) predictions: the high temperatures, characteristic of the time of the beginning of the flood, can affect the solubility of oxygen in the water, decreasing further this gas availability.

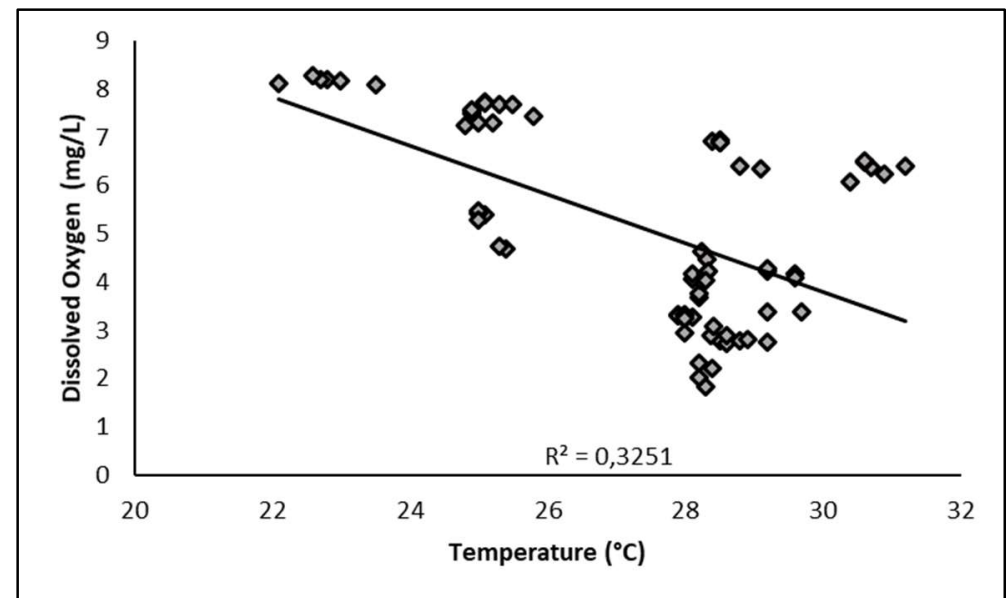

Figure 6: The relation between DO and temperature at the sampling points. (P1 to P6) from July 2018 to June 2019. The line denotes the negative relation trend.

The decoada period identified also shows a reduction in $\mathrm{pH}$ values and an increase in turbidity values (Figure 7). Although there is no significant difference between the sampling points and seasonal periods for these two variables, it is noted that the oxygen reduction in water was negatively related to the increase in 
$\mathrm{pH}$ values (Figure 8; $\mathrm{R}^{2}=0.37 ; \mathrm{p}<0.05$ )

The $\mathrm{pH}$ values in October and November were the lowest of the entire period studied (5.04 and 5.61, respectively), below recommended by CONAMA/357 (between 6 and 9 for class II rivers). This fact may be correlated with an increase in dissolved carbon dioxide (free $\mathrm{CO} 2$ ) and methane, as well as nutrients, with water acidification (CALHEIROS et al., 1998; HAMILTON et al., 1997; OLIVEIRA et al., 2013). During the subsequent months, the $\mathrm{pH}$ increased from 5.04 to 7.48 , which may be due to the increase in electrical conductivity in this period (data not shown).

The turbidity showed an average of $24.25 \pm 8.88$ NTU at the analyzed points. It should be noted that October and November registered the maximum values of turbidity for all sampling points, which may be associated with the large volume of rain in October $(330.4 \mathrm{~mm})$. This fact may be linked to the increase in runoff due to the occurrence of the first rains after months of drought and accumulation of material in the drainage basin. Although turbidity has not shown a significant relationship with $\mathrm{DO}$, the increase in turbidity may have contributed to the decoada phenomenon.

Although the turbidity has not reached the maximum limits established by CONAMA resolution 357/2005 (100 NTU), we consider that the slight increase in turbidity may have helped the decoada phenomenon formation. This implies that a recurring natural phenomenon in the Pantanal affects the parameters recommended by national legislation, and this particularity must be taken into account when we highlight the measures for the use and water resources management.



Figure 7: Turbidity and $\mathrm{pH}$ dynamics at sample points during the study period.

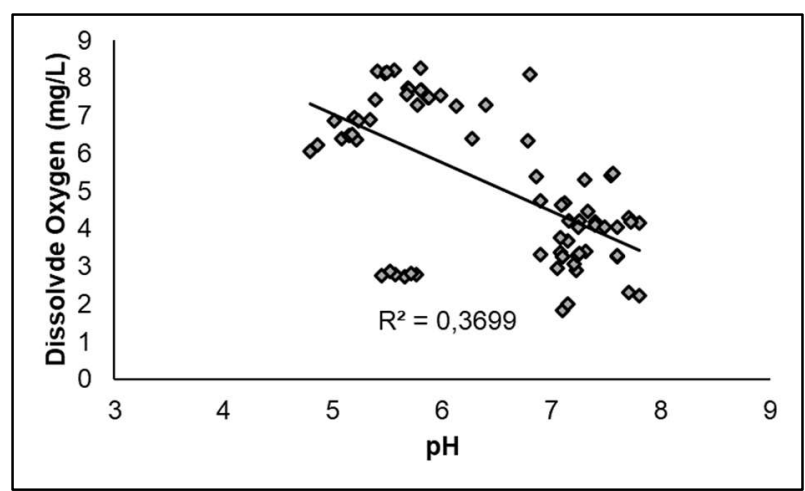

Figure 8: The relation between $\mathrm{DO}$ and $\mathrm{pH}$ at the sampling points (P1 to P6) from July 2018 to June 2019. The line denotes the negative relation trend.

No statistical difference was found between the DO parameters and suspended solids ( $p>0.05)$, which had an average concentration of $40 \pm 7.86 \mathrm{mg} / \mathrm{L}$ throughout the study period. However, it is worth mentioning a higher concentration of suspended solids in the months of August, September and October for the point $\mathrm{P} 2$, which may be associated with domestic sewage, released in the Paraguay River, through the Sangradouro stream. The input of water from an urban stream in a bay does not dilute completely, even during periods of high waters, which can further aggravate the occurrence of the decoada. During the low water months, the increase in the concentration of solids from the stream does not cause the phenomenon due to the high concentrations of oxygen in this region $(>5 \mathrm{mg} / \mathrm{L}$ ). 
When performing the principal component analysis (PCA) of the river and bay, to visualize the arrangement of parameters that influenced the decoada phenomenon, axes 1 and 2 of the bay and river can explain 71.22 and $69.82 \%$ respectively, and can be visualized in Figures 9 and 10. Regarding the PCA, it is noticed that the data in the river, belong to the group without decoada, however, when analyzed in the bay, it was verified that part of the decoada group is outside the larger group (without decoada), is distinct. The parameters that showed a relationship with the decoada were $\mathrm{pH}$, temperature, precipitation, turbidity and dissolved oxygen.

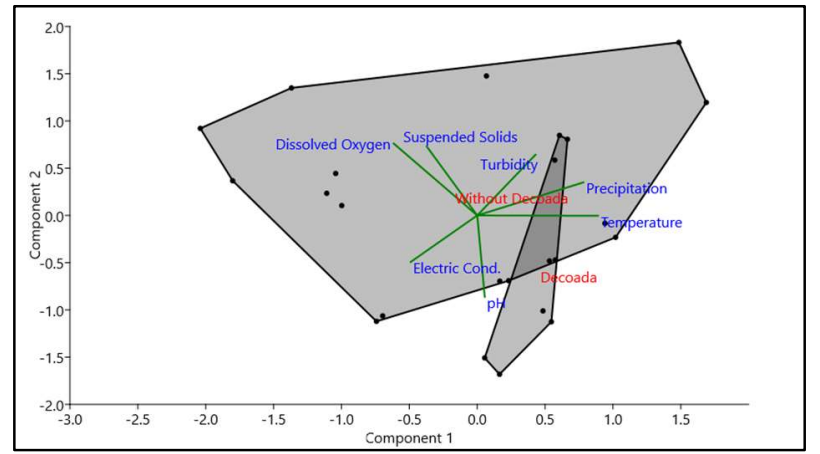

Figure 9: PCA demonstrating the parameters and its ordering that influenced the bay 'without decoada' and 'with decoada' groups. The green lines represent the parameter ordering (in blue) in two data groups (gray) 'without decoada' (DO> $3 \mathrm{mg} / \mathrm{L}$ ) and 'with decoada' (DO $<3 \mathrm{mg} / \mathrm{L})$.

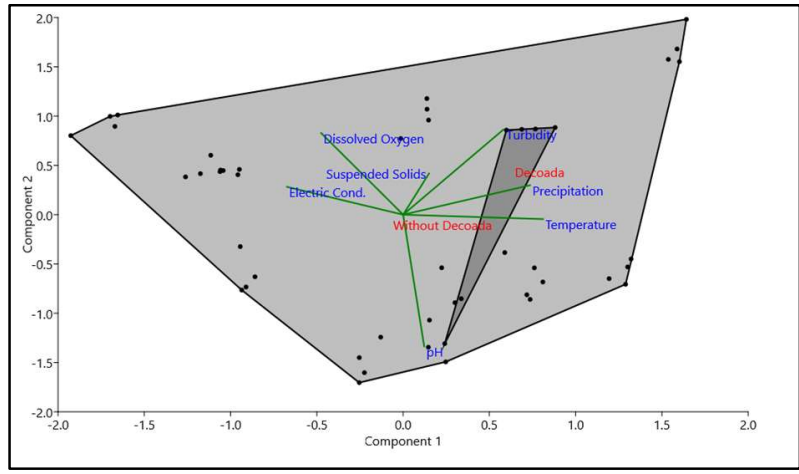

Figure 10: PCA demonstrating the parameters and its ordering that influenced the river 'without decoada' and 'with decoada' groups. The green lines represent the ordering of the parameter (in blue) in two data groups (gray) 'without decoada' (DO> $3 \mathrm{mg} / \mathrm{L}$ ) and with 'with decoada' (DO $<3 \mathrm{mg} / \mathrm{L})$.

\section{CONCLUSIONS}

The natural phenomenon decoada interferes directly in the water quality of the Paraguay River, which must be very careful when carrying out analyzes under the CONAMA Resolution 357/2005 and Water Quality Index (IQA) because the low concentrations of DO are not the anthropic activities results, but a natural phenomenon that occurs in the Pantanal during periods of high water. The definition of the decoada period depends, mainly on the precipitation and the increase in the river level (flood pulse), which the months that are subject to this phenomenon, in the studied area, are from November to April.

There were no decoada records considered high level, as found in the southern Pantanal, where DO can reach anoxia, having the potential to cause significant fish mortality. However, as seen in this work, this event can occur with low and medium intensity. The results showed that the decoada phenomenon presented itself differently in the bay and the river, with greater numbers of events and intensity in the bay, mainly due to the lower water flow renewal in this channel.

Finally, it is worth highlighting the importance of continuing this study, since the evaluation of the watercourses' quality is extremely important, and should be tested, according to the particularity of each hydrographic basin, to propose appropriate measures for environmental and water resources management.

In this way, we consider that the decoada phenomenon in the Pantanal affects the water quality in the parameters recommended by national legislation. Its occurrence is not continuous and is mainly initiated by the sudden rainfall increase. The occurrence is noticed mainly in marginal bodies with slower flow rates. 
The parameters tend to return to normal between 3 and 4 months after the first signs. Thus, we consider that the natural decoada phenomenon, even in low intensity, it significantly affects the water quality according to the parameters used for bathing in the national legislation.

\section{REFERENCES}

ALHO, C. J. R.. Biodiversity of the Pantanal: its magnitude, human occupation, environmental threats and challenges for conservation. Brazilian Journal of Biology, v.71, n.1, p.229-232, 2011.

ANDRADE, M. H. S.; BRANDIMARTE, A. L.; CALHEIROS, D. F.; TAMBOSI, L.. Caracterização limnológica de dois ambientes de área d inundação do rio Paraguai, Pantanal de Mato Grosso do Sul, com ênfase no fenômeno da 'decoada'. In: Simpósio de Geotecnologias no Pantanal, 5. Anais. Campo Grande: INPE, 2014. p.220-230.

BASTVIKEN, D.; SANTORO, A. L.; MAROTTA, H.; PINHO, L. Q.; CALHEIROS, D. F.; ENRICH-PRAST, A.. Methane emission from Pantanal, South America, during the low water season:toward more comprehensive sampling. Environmental Science \& Technology, v.44, n.14, 2010.

BRASIL. Ministério do Interior. Estudos de Desenvolvimento Integrado da Bacia do Alto Paraguai (EDIBAP): Relatório da 1a Fase. Descrição física e recursos naturais. Brasília, 1979.

BRASIL. Ministério do Meio Ambiente, dos Recursos Hídricos e da Amazônia Legal. Plano de conservação da Bacia do Alto Paraguai: diagnóstico dos meios físicos e biótico. Meio físico. Brasília: Ministério do Meio Ambiente, dos Recursos Hídricos e da Amazônia Legal, 1997.

BRASIL. Resolução n. 274. Dispõe sobre os parâmetros de qualidade da água para balneabilidade e dá outras providências. Brasília: DOU, 2000.

BRASIL. Resolução n. 357. Dispõe sobre a classificação dos corpos de água e diretrizes ambientais para o seu enquadramento, bem como estabelece as condições e padrões de lançamento de efluentes, e dá outras providências. Brasília: DOU, 2005.

BUHLER, B. F.. Qualidade da água e aspectos sedimentares da bacia hidrográfica do rio Paraguai no trecho situado entre a baía do late e a região do Sadao, município de Cáceres/MT, sob os enfoques quantitativos e perceptivos. Dissertação (Mestrado em Ciências Ambientais) Universidade do Estado de Mato Grosso, Cáceres, 2011.

CALHEIROS, D. F.. Influência do pulso de inundação na composição isotópica ( $\delta^{13} \mathrm{Ce} \delta^{15} \mathrm{~N}$ ) das fontes primárias de energia na planície de inundação do rio Paraguai (Pantanal - MS). Tese (Doutorado em Energia Nuclear na Agricultura) Universidade de São Paulo, Piracicaba, 2003.

CALHEIROS, D. F.; FERREIRA, C. J. A.. Alterações limnológicas no rio Paraguai ('Dequada') e o fenômeno natural de mortandade de peixes no Pantanal Matogrossense/MS. Boletim de Pesquisa e Desenvolvimento. Corumbá: EMBRAPA Pantanal, 1997

CALHEIROS, D. F.; HAMILTON, S. K.. Limnological conditions associated with natural fish kills in the Pantanal wetland of Brazil. Verhandlungen: Internationale Vereinigung fur Theorestische und Angewandte limnologie, v.26, p.21892193, 1998.

CALHEIROS, D. F.; OLIVEIRA, M. D.. O Rio Paraguai e sua planície de inundação: o Pantanal Mato-Grossense. Ciência \& Ambiente, 2010

CALHEIROS, D. F.; SEIDL, A. F.; FERREIRA, C. J. A.. Participatory research methods in environmental science:local and scientific knowledge of a limnological phenomenon in the Pantanal wetland of Brazil. Journal of Applied Ecology, v.37, p.684-696, 2000.

CARVALHO, N. O.. Hidrologia da Bacia do Alto Paraguai. In: Simpósio sobre Recursos Naturais e Socioeconômicos do Pantanal. In: PRIMEIRO SIMPÓSIO SOBRE RECURSOS NATURAIS E SOCIOECONÔMICOS DO PANTANAL. Anais. Brasília: Departamento de Difusão de Tecnologia, 1986. p.43-50.

CUNHA, S. B.; GUERRA, A. J. T.. Degradação ambiental. In: GUERRA, A. J. T.; CUNHA, S. B.. Geomorfologia e meio ambiente. 7 ed. Rio de Janeiro: Bertrand Brasil, 2009.

GONÇALVES, H. C.; MERCANTE, M. A.; SANTOS, E. T.. Hydrological cycle. Brazilian Journal of Biology, v.71 n.1, p.229-232, 2011.

HAMILTON, S. K.; SIPPEL, S. J.; CALHEIROS, D. F.; MELACK, J. M.. An anoxic event and the other biogeochemical effects of the Pantanal wetland on the Paraguay River. Limnology and Oceanography, v.42, p.257-272, 1997.

HAMILTON, S. K.; SIPPEL, S. J.; MELACK, J. M.. Oxygen depletion and carbon dioxide and methane production in waters of the Pantanal wetland of Brazil. Biogeochemistry, v.30, p.115-141, 1995.

HAMILTON, S. K.; SIPPEL, S. J.; MELACK, J. M.. Comparison of inundation patterns among major South American floodplains. Journal of Geophysical Research, v.107, n.D20, p.1-14, 2002

HAMMER, O.; HARPER, D. A. T.; RYAN, P. D.. PAST: Paleontological Statistic software package for education and data analysis. Paleontologia Eletronica, v.4 n.1, p.1-9, 2001

JUNK, W. J.; SILVA, C. J.. O conceito do pulso de inundação e suas implicações para o Pantanal de Mato grosso. In: CONGRESSO DE ECOLOGIA DO BRASIL, 6; SIMPÓSIO SOBRE RECURSOS NATURAIS E SÓCIOS-ECONÔMICOS DO PANTANAL, 1. Anais. Fortaleza, 2003. p.17-28.

JUNK, W. J.; BAYLEY, P. B.; SPARKS, R. E.. The flood pulse concept in river: floodplain-systems. Canadian Special Publications for Fisheries and Aquatic Sciences, v.106, 
p.110-127, 1989.

MATO GROSSO, Secretaria de Estado do Meio Ambiente. Superintendência de Recursos Hídricos. Relatório de Monitoramento da Qualidade da Água do Estado de Mato Grosso: 2015-2017. Cuiabá: SEMA/MT, 2018.

NEVES, M. A. S. N.; NUNES, M. C. N.; NEVES, R. J.. Caracterização das condições climáticas de Cáceres/MTBrasil, no período de 1971 a 2009: Subsídio às atividades agropecuárias e turísticas municipais. Boletim Goiano De Geografia, v.31, n.2, p.55-68, 2012. DOI: http://doi.org/10.5216/bgg.V31i2.16845

OLIVEIRA, M. D.; CALHEIROS, D. F.. Flood pulse influence on phytoplankton communities of the South Pantanal floodplain, Brazil. Hydrobiologia, v.427, p.102-112, 2000
OLIVEIRA, M. D.; CALHEIROS, D. F.; PADOVANI, C. R.. Mapeamento e descrição das áreas de ocorrência dos eventos de decoada no Pantanal. Boletim de Pesquisa e Desenvolvimento, v.121, p.1-21, 2013.

SILVA, A.; SOUZA, C. A.; ZANI, H.; FREITAS, D. R.. Avaliação da Margem Direita do Rio Paraguai a Jusante da Praia do Julião, Município de Cáceres (MT). Revista Geográfica Acadêmica, v.1, n.1, p.5-19, 2007

SILVA, J. S. V.; ABDON, M. M.. Delimitação do Pantanal brasileiro e suas sub-regiões. Pesquisas Agropecuária Brasileira, v.33, p.1703-1711, 1998.

ZANI, H.; ASSINE, M. L.; SILVA, A.. Batimetria fluvial estimada com dados orbitais: um estudo de caso no alto curso da bacia do rio Paraguai com sensor áster. Geociências, São Paulo, v.27, n.4, p.555-565, 2008.

A CBPC - Companhia Brasileira de Produção Científica (CNPJ: 11.221.422/0001-03) detém os direitos materiais desta publicação. Os direitos referem-se à publicação do trabalho em qualquer parte do mundo, incluindo os direitos às renovações, expansões e disseminações da contribuição, bem como outros direitos subsidiários. Todos os trabalhos publicados eletronicamente poderão posteriormente ser publicados em coletâneas impressas sob coordenação da Sustenere Publishing, da Companhia Brasileira de Produção Científica e seus parceiros autorizados. Os (as) autores (as) preservam os direitos autorais, mas não têm permissão para a publicação da contribuição em outro meio, impresso ou digital, em português ou em tradução. 